\title{
Treatment by Electrocoagulation of Congo red from Aqueous Solution Using Cantor Alloy
}

\author{
Gülizar Kurtoğlu Akkaya ${ }^{1 *}$, Gökhan Polat ${ }^{2}$, \\ ${ }^{1 *}$ Necmettin Erbakan University, Environment Engineering Deparment, Konya, Turkey, (ORCID: 0000-0003-4779-0428), ka.gulizar@gmail.com \\ ${ }^{2}$ Necmettin Erbakan University, Metallurgical and Materials Engineering Deparment, Konya, Turkey, (ORCID: 0000-0003-0143-900X), gpolat@erbakan.edu.tr
}

(International Conference on Design, Research and Development- 15 - 18 Aralık 2021)

(DOI: 10.31590/ejosat.1041536)

ATIF/REFERENCE: Akkaya, G.K., Polat, G., (2021). Treatment of Wastewaters by Electrocoagulation Using Cantor Alloy. European Journal of Science and Technology, (32), 791-796.

\begin{abstract}
Electrocoagulation (EC) is one of the most effective techniques in removing color and organic pollutants from wastewater. This study aims to use a new alloy system, so-called High Entropy Alloys (HEAs), which contains at least five principal elements with 5-35 at. \%, as an electrode in the EC process. The well-studied equiatomic CrMnFeCoNi HEA (Cantor alloy) was used as an anode in the treatment of the synthetically prepared wastewater (congo red solution) with EC. In the EC study, COD and color removal were evaluated at different current densities $(5-100 \mathrm{~mA} / \mathrm{cm} 2)$ for $15 \mathrm{~min}$ electrolysis period. The results showed that removal efficiency of above $80 \%$ was obtained for both parameters of COD and color at the lowest current density of $5 \mathrm{~mA} / \mathrm{cm}^{2}$. The optimum current density was determined to be $10 \mathrm{~mA} / \mathrm{cm}^{2}$, and the COD and color removal efficiencies were found to be 84 and $99.4 \%$, respectively. It was shown that the Cantor alloy possesses an effective removal in the EC process.
\end{abstract}

Keywords: Electrocoagulation, congo red, high entropy alloy, cantor alloy, COD removal.

\section{Cantor Alaşımı Kullanılarak sulu çözeltiden Kongo Kırmızısının Elektrokoagülasyon ile Arıtımı}

$\ddot{O} \mathbf{z}$

Elektrokoagülasyon (EC) atıksudan renk ve organik kirleticileri uzaklaştırmak için en etkili tekniklerden biridir. Bu çalışmada, en az beş temel element ve herbir element için \% at. 5-35 içeren Yüksek Entropi Alaşımları (HEA) olarak adlandırılan yeni bir alaşım sisteminin EC prosesinde elektrot olarak kullanılması hedeflenmiştir. Yoğun şekilde çalışılan eşit atomlu CrMnFeCoNi HEA (Cantor alaşımı), sentetik olarak hazırlanmış congo red çözeltisinin EC ile arıtılmasında anot olarak kullanılmıştır. Yapılan EC çalışması 15 dakika elektroliz süresinde farklı akım yoğunluklarında $\left(5-100 \mathrm{~mA} / \mathrm{cm}^{2}\right)$ KOİ ve renk giderimi değerlendirilmiştir. Deney sonucunda, akım yoğunluğu $5 \mathrm{~mA} / \mathrm{cm}^{2}$, her iki renk ve KOİ parametrede \% 80 üzeri arıtım verimi elde edilmiştir. Optimum akım yoğunluğu ise 10 $\mathrm{mA} / \mathrm{cm}^{2}$ olarak belirlenmiş, KOİ ve renk giderim verimi sırasıyla \% 84 ve 99,4 olarak bulunmuştur. Yapılan bu çalışma neticesinde, kullanılan Cantor alaşımının EC procesinde giderimde etkili olduğu gösterilmiştir.

Anahtar Kelimeler: Elektrokoagülasyon, kongo kırmızısı, yüksek entropi alaşımı, cantor alaşımı, KOİ giderimi.

\footnotetext{
*Corresponding Author: ka.gulizar@gmail.com
} 


\section{Introduction}

Increasing industrialization and urbanization are increased environmental pollution, and therefore, fresh water resources are depleted (Asghar et al., 2020). Industrial facilities play a critical role due to the discharge of toxic wastes into receiving water bodies and mostly result in dyes. Dyes are annually produced from many industries such as textile, cosmetics, paper, food, leather, and other industries. Therefore, water contaminated with dyes is highly polluted, colored, turbidity and it has high chemical oxygen demand (COD). They cause an important harmful impact on the aesthetics of the aquatic environment and have damaging consequences on organisms (Khan et al., 2014). Thus, it is a necessity to apply conventional or advanced treatments to almost $90 \%$ of the water consumed in the industry prior to discharging into the ecosystem (Silva et al., 2018).

Dyes are refractory pollutants and are treated using advanced treatment technologies (Asghar et al., 2020; Bello et al., 2020; Bahadur \& Bhargava, 2019 ; Asghar, Raman, et al., 2017) such as fenton oxidation (Asghar, Abdul Raman, et al., 2017), ozonation (Wang et al., 2019), ultrasound (Asghar et al., 2020), electrochemical oxidation-reduction (Cortés et al., 2007), indirect electro-oxidation using strong oxidants (Liu et al., 2019), electrocoagulation (EC) (Huda et al., 2017), and advanced oxidation processes (AOPs). AOPs show higher efficiency, however, result in high chemical consumption (Buthiyappan \& Raman, 2019) and limit their wide applications (Khandegar \& Saroha, 2013). In this respect, the EC process has been used to treat wastewater with different characteristics due to its moderate chemical requirement, versatility, safety, selectivity, ease of control, and automation (Thakur et al., 2009).

EC is a treatment process that removes pollutants from wastewater using electric current and metal electrodes. The metal electrodes used in the process react electrochemically with pollutants by producing water-soluble hydroxides with the applied electric current. Since the adsorption capacity of metal hydroxides is very high, metal hydroxides form coagulants by adsorbing different pollutant parameters in the water, and the formed coagulants are removed from the water by precipitating. Aluminum $\left(\mathrm{Al}^{+3}\right)$ and iron $\left(\mathrm{Fe}^{+3}, \mathrm{Fe}^{+2}\right)$ electrodes are commonly used in such processes. However, the passivation and corrosion of the electrodes over time is a disadvantage in the EC process and affects the pollutant removal efficiency along with the treatment cost. Therefore, many different metallic electrodes and alloys have been investigated to be used in EC (Dura, 2013a).

An inspection of the literature shows various alloy electrodes were used in wastewater treatment with EC (Donneys-Victoria et al., 2020; Molano-Mendoza et al., 2019; Dura, 2013b). They pointed out that conventionally alloys provide a more efficient wastewater treatment compared to pure metals (Aitbara et al., 2021). Therefore, the alloys containing more than one element possess better removal efficiency compared to their pure counterparts. The recent studies in materials science show that a novel alloys system, so-called high entropy alloys (HEAs), contains at least five principal elements and compositions of 5-35 at. \%. These alloys show higher mixing entropy in a liquid or solid solution to stabilize the expected phases (Murty et al., 2019).
These alloy systems show higher mechanical (Kao et al., 2009), magnetic (Chaudhary et al., 2021), thermal properties (Kukshal et al., 2018) as well as corrosion (Shi et al., 2017), and oxidation (Holcomb et al., 2015) resistance than conventional alloy systems. Thus, they have received much attention due to their potentially desirable properties. The well-studied equiatomic CrMnFeCoNi HEA (Cantor alloy) with a single face-centered cubic (FCC) structure possesses exceptional corrosion behavior than the stainless-steel counterparts (Shi et al., 2017)(Luo et al., 2018). Additionally, the comparable properties of Cantor alloy with $\mathrm{Fe}$ and Al-based alloys promise potential applications in many fields like aqueous solutions (Qiu et al., 2017).

In the present study, the removal efficiency of Cantor HEA anodes in the EC process was studied in detail. To date, no study has been investigated the usage and effect of HEAs in the EC process.

\section{Material and Method}

\subsection{Preparation of Cantor Alloy}

Indutherm MC 15+ induction melting furnace were used to produce Cantor alloy from high purity raw materials $(>99.0 \mathrm{wt}$. $\%$ ). The melting process was carried out in an alumina crucible under an argon atmosphere to avoid oxidation. The liquid metal was also stirred by the magnetic field to ensure chemical homogeneity. The homogeneous alloy was cast into a copper mold having a $40 \mathrm{~mm} \times 60 \mathrm{~mm} \times 10 \mathrm{~mm}$ rectangular shape (Figure 1a).

\subsection{Experiment}

The aqueous solution was prepared by taking $1 \mathrm{~g}$ of Congo red, whose properties are given in Table 1, in $1 \mathrm{~L}$ of distilled water without $\mathrm{pH}$ adjustment. The experiments were carried out on Congo red solutions with a concentration of $500 \mathrm{mg} / \mathrm{L}$ prepared during the experiment. $2 \mathrm{mg} / \mathrm{L} \mathrm{NaCl}$ was added to increase the ionic strength of the solution. The EC reactor was made of Plexiglas, with a diameter of $19 \mathrm{~cm}$ and a height of $15 \mathrm{~cm}$ (Figure 1b). The EC working volume was $250 \mathrm{~mL}$. In the study, Cantor alloy was used as the anode, aluminum as the cathode ( $4 \mathrm{~cm}$ wide, $5 \mathrm{~cm}$ high and $0.5 \mathrm{~cm}$ thickness) and a distance of $2 \mathrm{~cm}$ was set between the electrodes. The total effective electrode area was determined to be $24 \mathrm{~cm}^{2}$. The reactor was supplied with a direct current power supply. Experiments were conducted in Congo red solution with initial an initial $\mathrm{pH}$ value of 7 and a conductivity of $4.02 \mathrm{mS} / \mathrm{cm}$, at different current densities $\left(5-100 \mathrm{~mA} / \mathrm{cm}^{2}\right)$ for $15-$ minute electrolysis time. A sufficient distance was left between the bottom of the electrodes and the cell for efficient mixing. A homogeneous mixture of the solution was provided using a magnetic stirrer at $250 \mathrm{rpm}$. The electrodes were washed at least 2 times before each experiment.

\section{Table 1. Congo red properties}

\begin{tabular}{l|c}
\hline Formula & $\mathrm{C}_{32} \mathrm{G}_{22} \mathrm{~N}_{6} \mathrm{Na}_{2} \mathrm{O}_{6} \mathrm{~S}_{2}$ \\
\hline Formula Weight & $696.68 \mathrm{~g} / \mathrm{mol}$ \\
\hline Brand & ISOLAB \\
\hline Product Number & $911 . \mathrm{D} 01$ \\
\hline Appearance & Brownish red powder \\
\hline
\end{tabular}




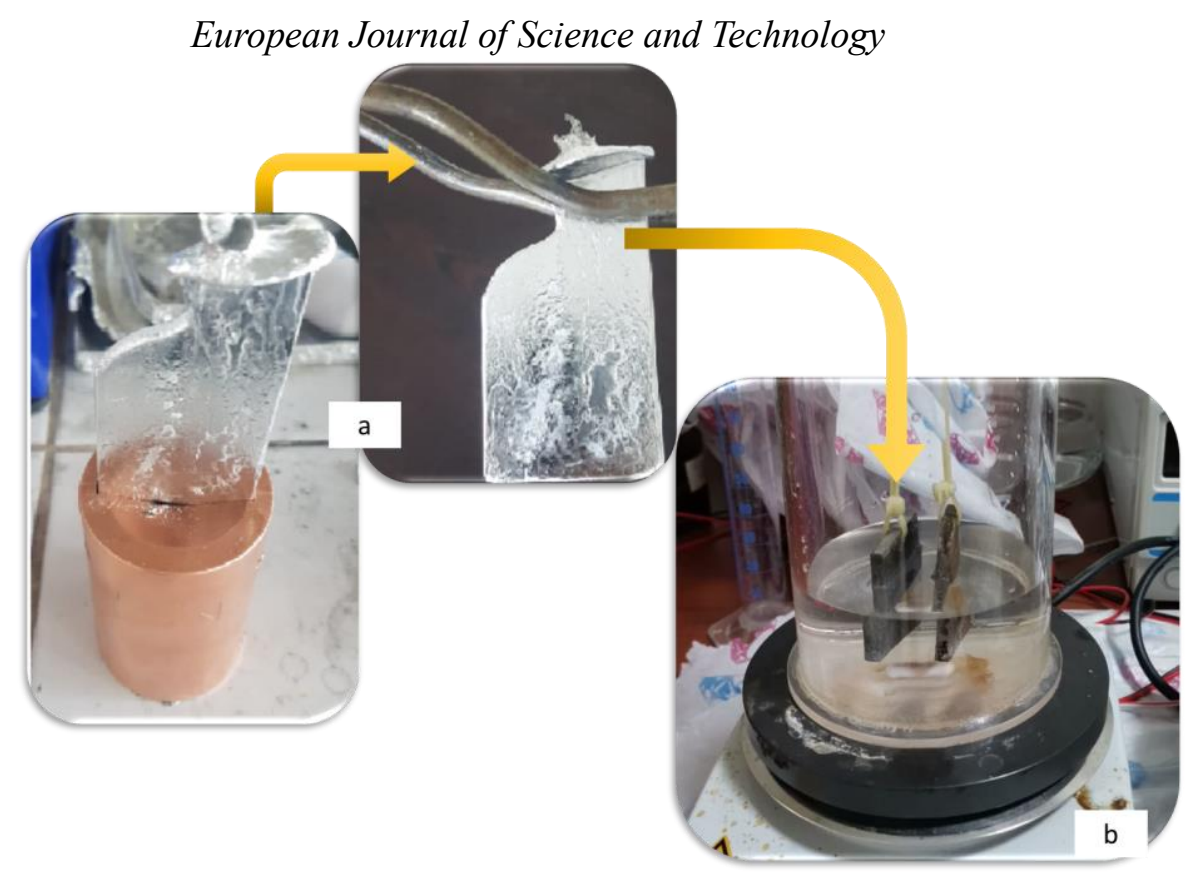

Figure 1. Preparation Cantor Alloy (a) EC process (b).

\subsection{Analysis}

The final $\mathrm{pH}$ and conductivity changes were recorded after EC studies at different current densities of Congo red solutions with the same initial $\mathrm{pH}$ and conductivity. $\mathrm{pH}$ value and the conductivity of the solutions were measured using the Hach Lange/HQ40d kit. The samples obtained after the EC sets were kept for 1 day to obtain the best removal efficiency. Afterward, the Hach UV/Vis DR5000 spectrophotometer was used for the COD and color removal of the supernatants. COD was analyzed according to the Standard Method 5220-D. Congo red starting $\mathrm{COD}$ and color concentrations were $500 \mathrm{mg} / \mathrm{L}$ and $6350 \mathrm{ADMI}$. COD and Color removals were calculated according to equations (1) and (2).

$C O D \%=\frac{C O D_{0}-C O D_{1}}{C O D_{0}} \times 100$

Decolorization $(\%)=\frac{\lambda_{0}-\lambda}{\lambda_{0}} \times 100$

\section{Results and Discussion}

In EC processes, the current density controls the reaction rate in the reactor since it regulates the coagulation rate and flotation rate. Therefore, it is one of the most critical parameters affecting EC (Mollah et al., 2004; Chen, 2004). EC was performed using different current densities to study its effect on COD and decolorization efficiency.

COD removal at various current densities is shown in Figure 2. It is seen in the figure that the current density was increased systematically from $5 \mathrm{~mA} / \mathrm{cm}^{2}$ to $50 \mathrm{~mA} / \mathrm{cm}^{2}$, and the highest COD removal efficiency of $86 \%$ was obtained at $50 \mathrm{~mA} / \mathrm{cm}^{2}$. It can be due to the higher removal efficiency of pollutants with increasing current density, the higher number of ions produced on the electrodes which support the destabilized pollutant molecules, and thus, the agglomeration of the flocs formed due to the increase in hydrogen formation (Cerqueira et al., 2009). In this case, it can be explained by the accumulation of metal hydroxides in the environment by increasing the current density that continues to be applied to the alloy. The optimum current density was determined as $10 \mathrm{~mA} / \mathrm{cm}^{2}$. COD removal efficiency of $84 \%$ was obtained at $10 \mathrm{~mA} / \mathrm{cm}^{2}$. Although the highest removal efficiency was obtained at $50 \mathrm{~mA} / \mathrm{cm}^{2}$, the optimum current density was determined as $10 \mathrm{~mA} / \mathrm{cm}^{2}$ since applying 5 times higher current density for $4 \%$ removal efficiency cause an increase in the energy cost.

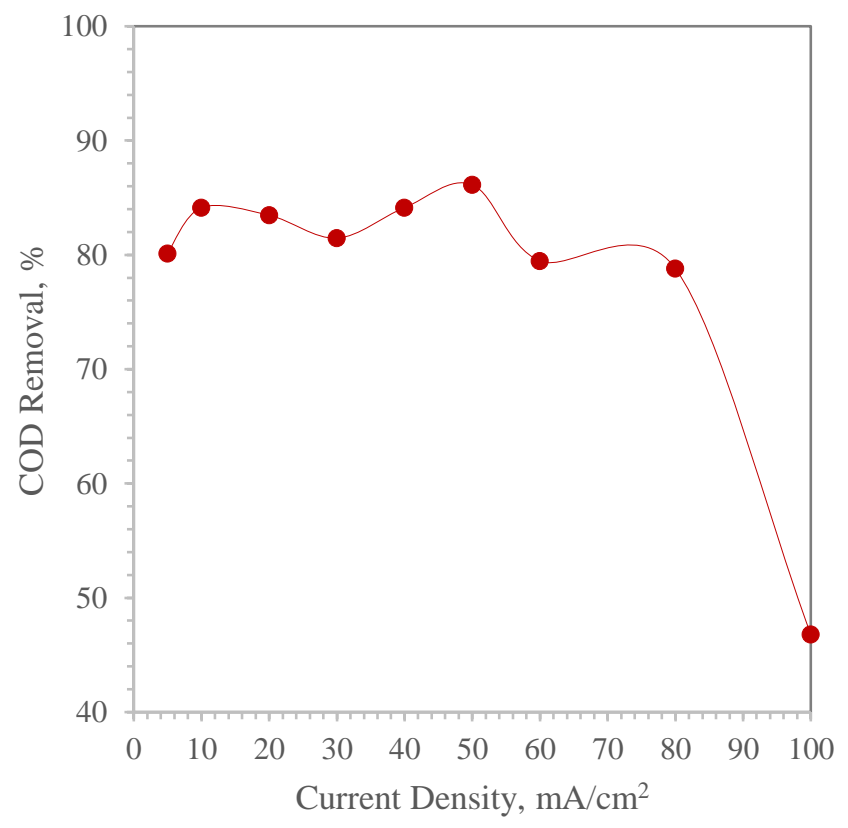

Figure 2. Influence of current density on COD removal

Color removal efficiencies depending on different current densities are given in Figure 3. The removal efficiency was above $90 \%$ at all current densities. Metals ions produced from the $\mathrm{CrMnFeCoNi}$ alloy reacted almost all of the congo red molecules. 
However, an insignificant but slight decrease in color removal was observed with the increasing current density. The previous studies showed that color removal increased with the increase in the current density (Daneshvar et al., 2006) Pajootan et al., 2012; Mohammadlou et al., 2014), while it created a small but insignificant effect in this study. Considering the final $\mathrm{pH}$ of congo red after EC, the increase in $\mathrm{pH}$ occurred with the increase in current density. The change in $\mathrm{pH}$ affecting the color removal emphasizes that the removal of dyes depends on operating parameters such as $\mathrm{pH}$ and current density. It is stated that the use of $\mathrm{NaCl}$ as an electrolyte at neutral $\mathrm{pH}$ provides anodic oxidation of $\mathrm{Cl}$, and can affect color removal (Brillas \& Martínez-Huitle, 2015).

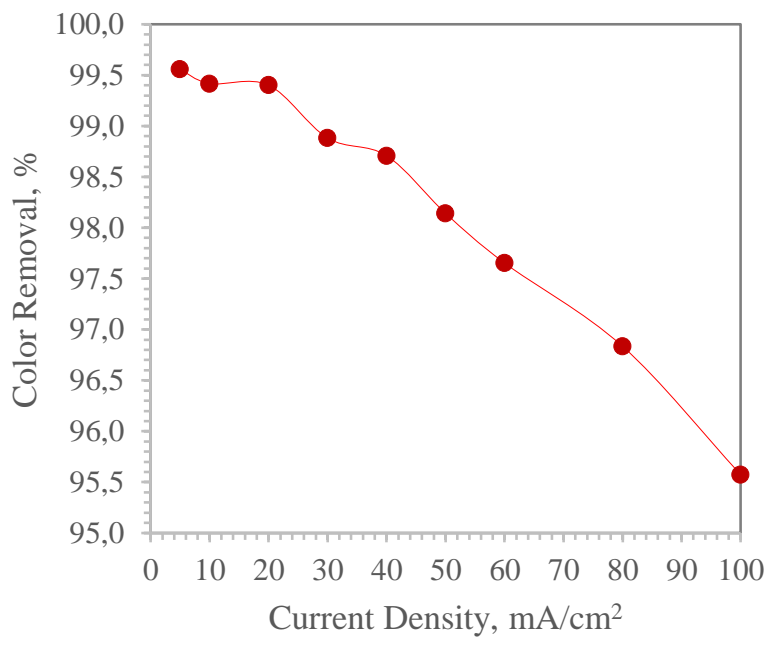

Figure 3. Influence of current density on color removal

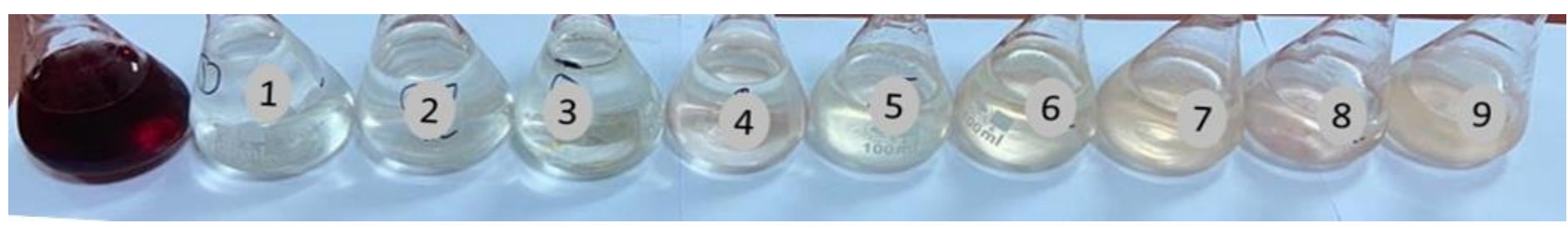

Figure 4. Color change after EC in different current densities $\left(1: 5 \mathrm{~mA} / \mathrm{cm}^{2}, 2: 10 \mathrm{~mA} / \mathrm{cm}^{2}, 3: 20 \mathrm{~mA} / \mathrm{cm}^{2}, 4: 30 \mathrm{~mA} / \mathrm{cm}^{2}, 5: 40\right.$ $\mathrm{mA} / \mathrm{cm}^{2}, 6: 50 \mathrm{~mA} / \mathrm{cm}^{2}, 7: 60 \mathrm{~mA} / \mathrm{cm}^{2}, 8: 80 \mathrm{~mA} / \mathrm{cm}^{2}, 9: 100 \mathrm{~mA} / \mathrm{cm}^{2}$, Electrolysis time: $15 \mathrm{~min}$ )

It is stated in the previous studies that the increasing current density increase the color and COD removal efficiencies (Cerqueira et al., 2009; Verma, 2017). However, the increasing current density increases the electricity and energy consumption leading to high costs for the process. Therefore, a treatment study at high current density reveals the disadvantages of the EC process. In addition, different metal anodes were examined and compared in the literature. For example, Armani et al. reported that $\mathrm{Fe}$ anode provides a more efficient COD and color removal than $\mathrm{Al}$ (Brillas \& MartínezHuitle, 2015). They showed that COD and color removal efficiencies of $84 \%$ and $99.4 \%$ were achieved at $10 \mathrm{~mA} / \mathrm{cm}^{2}$ for 15 mins using $\mathrm{Fe}$ anode.

Increasing the current density caused a change in the final $\mathrm{pH}$ and conductivity. This change in $\mathrm{pH}$ is a result of the $\mathrm{EC}$ mechanism. At the anode, the soluble metal (M) is dissociated into its ions by applying the current as given in Eq. (3).

$$
M_{(s)} \rightarrow M_{(a q)}^{n+}+n e^{-}
$$

Metal ions form coagulant species and metal hydroxides at a suitable pH (Eq. 4). During the EC, the large surface area of metal hydroxides causes rapid adsorption of soluble organic compounds and captures the colloidal particles. The forming heaps could be easily removed from the aqueous environment by precipitation or flotation (Feng et al., 2007). The elements in the CrMnFeCoNi HEA dissolved into metal ions with the applied current and formed metal hydroxides. It is stated that all elements have unique corrosion and adsorption capacities
(Vargel, 2020). Accordingly, COD and color removal efficiencies revealed that the pollutant adsorbing capacity of the CrMnFeCoNi HEA could be increased due to the presence of different metals.

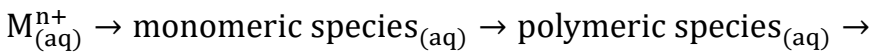
amorphous $\mathrm{M}(\mathrm{OH})_{\mathrm{n}(\mathrm{s})}$

The following reaction occurs at the cathode.

$2 \mathrm{H}_{2} \mathrm{O}_{(\mathrm{aq})}+2 \mathrm{e}^{-} \rightarrow \mathrm{H}_{2(\mathrm{~g})}+2 \mathrm{OH}^{-}$

It is seen in Eq. 5 that hydrogen is produced at neutral or alkaline $\mathrm{pH}$. In addition, it was observed that the final $\mathrm{pH}$ increased with increasing current density. It can be interpreted that this situation is caused by the increase of $\mathrm{OH}^{-}$ions dissolved in the cathode based on Eq. 5. On the other hand, the conductivity remained constant up to $30 \mathrm{~mA} / \mathrm{cm}^{2}$, after which it showed a tendency to increase (Figure 6). It can be interpreted that this situation was caused by the accumulation of ions in the water after the pollutant removal was completed. The increase in conductivity of water caused the formation of electrocorrosion. Although the conductivity remained constant up to $30 \mathrm{~mA} / \mathrm{cm}^{2}$, above which the increasing rate showed a smooth trend. Thus, it can be concluded that the electrode shows a corrosion-resistant property. 


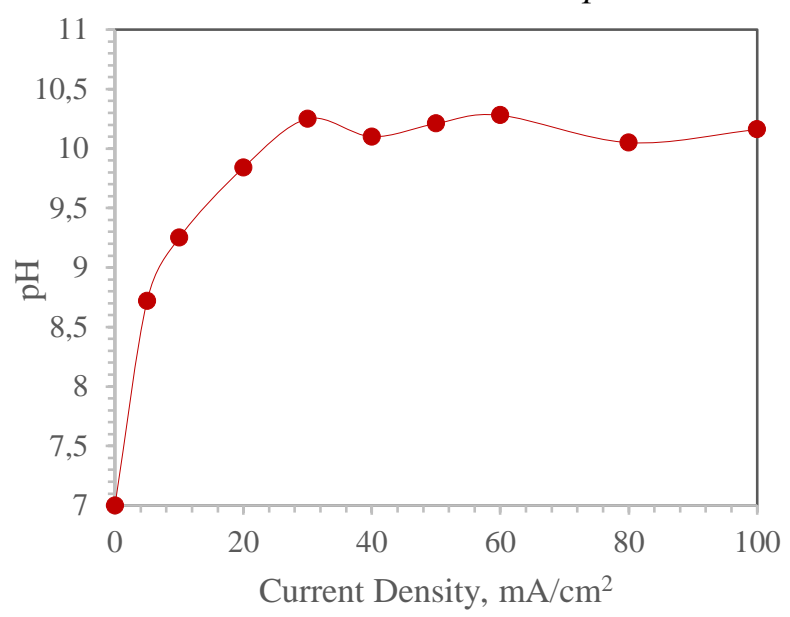

Figure 5. Change pH after EC in different current densities

\section{Conclusions and Recommendations}

In this study, the performance of a novel alloy system, so-called high entropy alloys (HEAs), which exhibit high corrosion behavior, in the treatment of wastewater with EC was evaluated. The well-known CrMnFeCoNi HEA (Cantor alloy) was used as an electrode the investigate its effect on COD and color removal efficiencies of synthetic dye solution at different current densities. $\mathrm{pH}$ and electrolysis time were kept constant during the process, and the best COD and color removal were obtained at $10 \mathrm{~mA} / \mathrm{cm}^{2}$, with values of 84 and $99.4 \%$, respectively. Since the Cantor alloy is effective at low current density, it can reduce the energy cost. Since HEAs are novel engineering materials, it is worth investigating their effect on the COD and color removal with various parameters.

\section{Acknowledgment}

The authors would like to thank the Department of Metallurgical and Materials Engineering, Middle East Technical University, for the production of high entropy alloys.

\section{References}

Aitbara, A., Khelalfa, A., Bendaia, M., Rahma Abrane, ·, Abdeltif Amrane, ', \& Hazourli, · Sabir. (2021). Treatment of dairy wastewater by electrocoagulation using A-U4G (2017-Al) alloy and pure aluminum as electrode material. EuroMediterranean Journal for Environmental Integration, 3, 19. https://doi.org/10.1007/s41207-020-00227-2

Asghar, A., Abdul Raman, A. A., \& Daud, W. M. A. W. (2017). Sequential optimization for minimizing material cost and treatment time of fenton oxidation for textile wastewater treatment. Chemical Engineering Communications, 204(8), 873-883.

Bahadur, N., \& Bhargava, N. (2019). Novel pilot scale photocatalytic treatment of textile \& dyeing industry wastewater to achieve process water quality and enabling zero liquid discharge. Journal of Water Process Engineering, 32, 100934.

Bello, M. M., Raman, A. A. A., \& Asghar, A. (2020). Activated

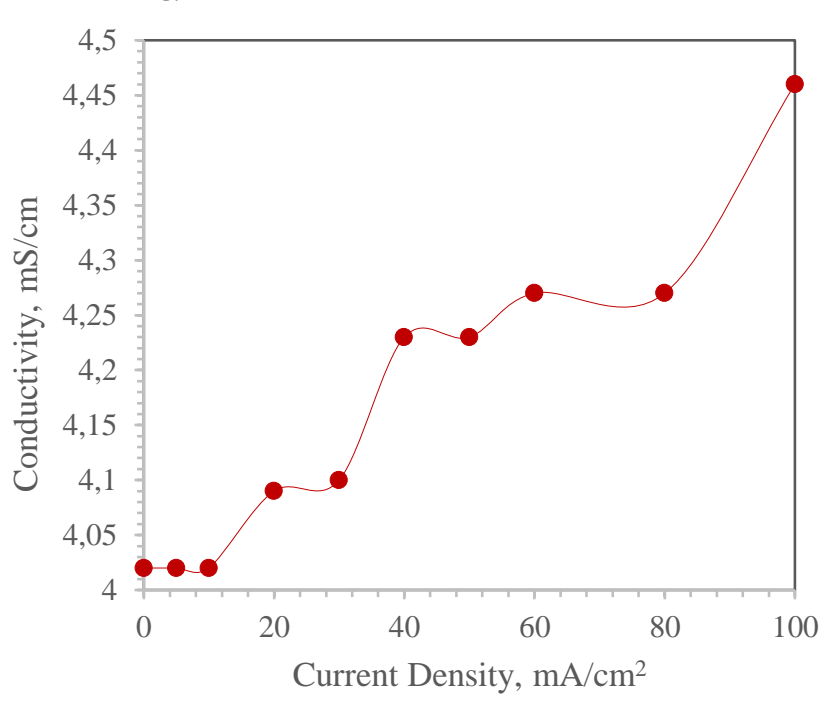

Figure 6. Change conductivity after EC in different current densities

carbon as carrier in fluidized bed reactor for Fenton oxidation of recalcitrant dye: Oxidation-adsorption synergy and surface interaction. Journal of Water Process Engineering, 33, 101001.

Brillas, E., \& Martínez-Huitle, C. A. (2015). Decontamination of wastewaters containing synthetic organic dyes by electrochemical methods. An updated review. Applied Catalysis B: Environmental, 166, 603-643.

Buthiyappan, A., \& Raman, A. A. A. (2019). Energy intensified integrated advanced oxidation technology for the treatment of recalcitrant industrial wastewater. Journal of Cleaner Production, 206, 1025-1040.

Cerqueira, A., Russo, C., \& Marques, M. R. C. (2009). Electroflocculation for textile wastewater treatment. Brazilian Journal of Chemical Engineering, 26(4), 659668.

Chaudhary, V., Chaudhary, R., Banerjee, R., \& Ramanujan, R. V. (2021). Accelerated and conventional development of magnetic high entropy alloys. Materials Today.

Chen, G. (2004). Electrochemical technologies in wastewater treatment. Separation and Purification Technology, 38(1), $11-41$.

Cortés, J. A., Alarcon-Herr, M. T., Pérez-Robles, J. F., VillicanaMéndez, M., \& González-Hernández, J. (2007). Kinetic degradation of acid blue 9 through the TiO2/UV advanced oxidation process. The Nanotechnology Conference and Trade Show.

Daneshvar, N., Oladegaragoze, A., \& Djafarzadeh, N. (2006). Decolorization of basic dye solutions by electrocoagulation: An investigation of the effect of operational parameters. Journal of Hazardous Materials, 129(1-3), 116-122. https://doi.org/10.1016/j.jhazmat.2005.08.033

Donneys-Victoria, D., Marriaga-Cabrales, N., MachucaMartínez, F., Benavides-Guerrero, J., \& Cloutier, S. G. (2020). Indigo carmine and chloride ions removal by electrocoagulation. Simultaneous production of brucite and layered double hydroxides. Journal of Water Process Engineering, 33, 101106. https://doi.org/10.1016/j.jwpe.2019.101106

Dura, A. (2013a). Electrocoagulation for water treatment: the removal of pollutants using aluminium alloys, stainless steels and iron anodes. National University of Ireland, Maynooth (Ireland). 
Dura, A. (2013b). Electrocoagulation for Water Treatment: the Removal of Pollutants using Aluminium Alloys, Stainless Steels and Iron Anodes. August, 1-306. http://eprints.maynoothuniversity.ie/6744/1/adelaidedura.pdf

Feng, J., Sun, Y., Zheng, Z., Zhang, J., Shu, L. I., \& Tian, Y. (2007). Treatment of tannery wastewater by electrocoagulation. Journal of Environmental Sciences, 19(12), 1409-1415.

Holcomb, G. R., Tylczak, J., \& Carney, C. (2015). Oxidation of CoCrFeMnNi high entropy alloys. Jom, 67(10), 23262339.

Huda, N., Raman, A. A. A., Bello, M. M., \& Ramesh, S. (2017). Electrocoagulation treatment of raw landfill leachate using iron-based electrodes: effects of process parameters and optimization. Journal of Environmental Management, 204, $75-81$.

Kao, Y.-F., Chen, T.-J., Chen, S.-K., \& Yeh, J.-W. (2009). Microstructure and mechanical property of as-cast,homogenized, and-deformed AlxCoCrFeNi $(0 \leq \mathrm{x} \leq 2)$ highentropy alloys. Journal of Alloys and Compounds, 488(1), 57-64.

Khan, M. Z., Singh, S., Sreekrishnan, T. R., \& Ahammad, S. Z. (2014). Feasibility study on anaerobic biodegradation of azo dye reactive orange 16. RSC Advances, 4(87), 4685146859.

Khandegar, V., \& Saroha, A. K. (2013). Electrocoagulation for the treatment of textile industry effluent-a review. Journal of Environmental Management, 128, 949-963.

Kukshal, V., Patnaik, A., \& Bhat, I. K. (2018). Corrosion and thermal behaviour of AlCr1. 5CuFeNi2Tix high-entropy alloys. Materials Today: Proceedings, 5(9), 17073-17079.

Liu, Y.-J., Hu, C.-Y., \& Lo, S.-L. (2019). Direct and indirect electrochemical oxidation of amine-containing pharmaceuticals using graphite electrodes. Journal of Hazardous Materials, 366, 592-605.

Luo, H., Li, Z., Mingers, A. M., \& Raabe, D. (2018). Corrosion behavior of an equiatomic $\mathrm{CoCrFeMnNi}$ high-entropy alloy compared with 304 stainless steel in sulfuric acid solution. Corrosion Science, 134, 131-139.

Mohammadlou, N., Rasoulifard, M. H., Vahedpour, M., \& Eskandarian, M. R. (2014). The kinetic and thermodynamic study for decolorization of Congo red from aqueous solution using electrocoagulation process. Journal of Applied Chemical Research, 8(4), 123-142.

Molano-Mendoza, M., Donneys-Victoria, D., Marriaga-Cabrales, N., Angel Mueses, M., Puma, G. L., \& Machuca-Martínez, F. (2019). Dataset on infrared spectroscopy and X-ray diffraction patterns of $\mathrm{Mg}-\mathrm{Al}$ layered double hydroxides by the electrocoagulation technique. Data in Brief, 27, 104564. https://doi.org/10.1016/j.dib.2019.104564

Mollah, M. Y. A., Morkovsky, P., Gomes, J. A. G., Kesmez, M., Parga, J., \& Cocke, D. L. (2004). Fundamentals, present and future perspectives of electrocoagulation. Journal of Hazardous Materials, 114(1-3), 199-210.

Murty, B. S., Yeh, J.-W., Ranganathan, S., \& Bhattacharjee, P. P. (2019). High-entropy alloys. Elsevier.

Pajootan, E., Arami, M., \& Mahmoodi, N. M. (2012). Binary system dye removal by electrocoagulation from synthetic and real colored wastewaters. Journal of the Taiwan Institute of Chemical Engineers, 43(2), 282-290.

Qiu, Y., Thomas, S., Gibson, M. A., Fraser, H. L., \& Birbilis, N. (2017). Corrosion of high entropy alloys. Npj Materials
Degradation, 1(1), 1-18.

Shi, Y., Yang, B., \& Liaw, P. K. (2017). Corrosion-resistant highentropy alloys: A review. Metals, 7(2), 43.

Silva, L. G. M., Moreira, F. C., Souza, A. A. U., Souza, S. M., Boaventura, R. A. R., \& Vilar, V. J. P. (2018). Chemical and electrochemical advanced oxidation processes as a polishing step for textile wastewater treatment: A study regarding the discharge into the environment and the reuse in the textile industry. Journal of Cleaner Production, 198, 430-442.

Thakur, C., Srivastava, V. C., \& Mall, I. D. (2009). Electrochemical treatment of a distillery wastewater: Parametric and residue disposal study. Chemical Engineering Journal, 148(2-3), 496-505.

Vargel, C. (2020). Corrosion of aluminium. Elsevier.

Verma, A. K. (2017). Treatment of textile wastewaters by electrocoagulation employing $\mathrm{Fe}-\mathrm{Al}$ composite electrode. Journal of Water Process Engineering, 20, 168-172.

Wang, J., Ji, Y., Zhang, F., Wang, D., He, X., \& Wang, C. (2019). Treatment of coking wastewater using oxic-anoxic-oxic process followed by coagulation and ozonation. Carbon Resources Conversion, 2(2), 151-156. 